Special Issue: Agricultural Productivity and Sustainability Improvement in Tropical Region

\title{
Comparison between Natural and Cabinet Drying on Weight Loss of Seaweed Euchuema cottonii Weber-van Bosse
}

\author{
Suwati Suwati ${ }^{1}$, Erni Romansyah,*, Syarifudin Syarifudin ${ }^{1}$, Yahya Jani ${ }^{2}$, Agus Heri Purnomo ${ }^{3}$, \\ Damat Damat ${ }^{4}$ and Erkata Yandri ${ }^{5,6}$
}

${ }^{1}$ Department of Agriculture Engineering, Faculty of Agriculture, Universitas Muhammadiyah Mataram, Jl. K. H. Ahmad Dablan No.1 Pagesangan, Mataram 83115, Nusa Tenggara Barat, Indonesia; ${ }^{2}$ Department of Urban Studies, Faculty of Culture and Society, Malmö University, Nordenskiöldsgatan 1, 21119 Malmo, Sweden; ${ }^{3}$ Research Center for Marine and Fisheries Socio-economics, Mina Bahari 1Building, Jl. Pasir Putib 1, Ancol, Jakarta 14430, Indonesia; ${ }^{4}$ Department of Food Science and Technology, University of Muhammadiyah Malang, Jl. Raya Tlogomas No. 246 Malang 65144, East Java, Indonesia; ${ }^{5}$ Graduate School of Renewable Energy, Darma Persada University, Jl. Radin Inten 2, Pondok Kelapa, East Jakarta 13450, Indonesia; ${ }^{6}$ Center of Renewable Energy Studies, Darma Persada University, East Jakarta 13450, Indonesia

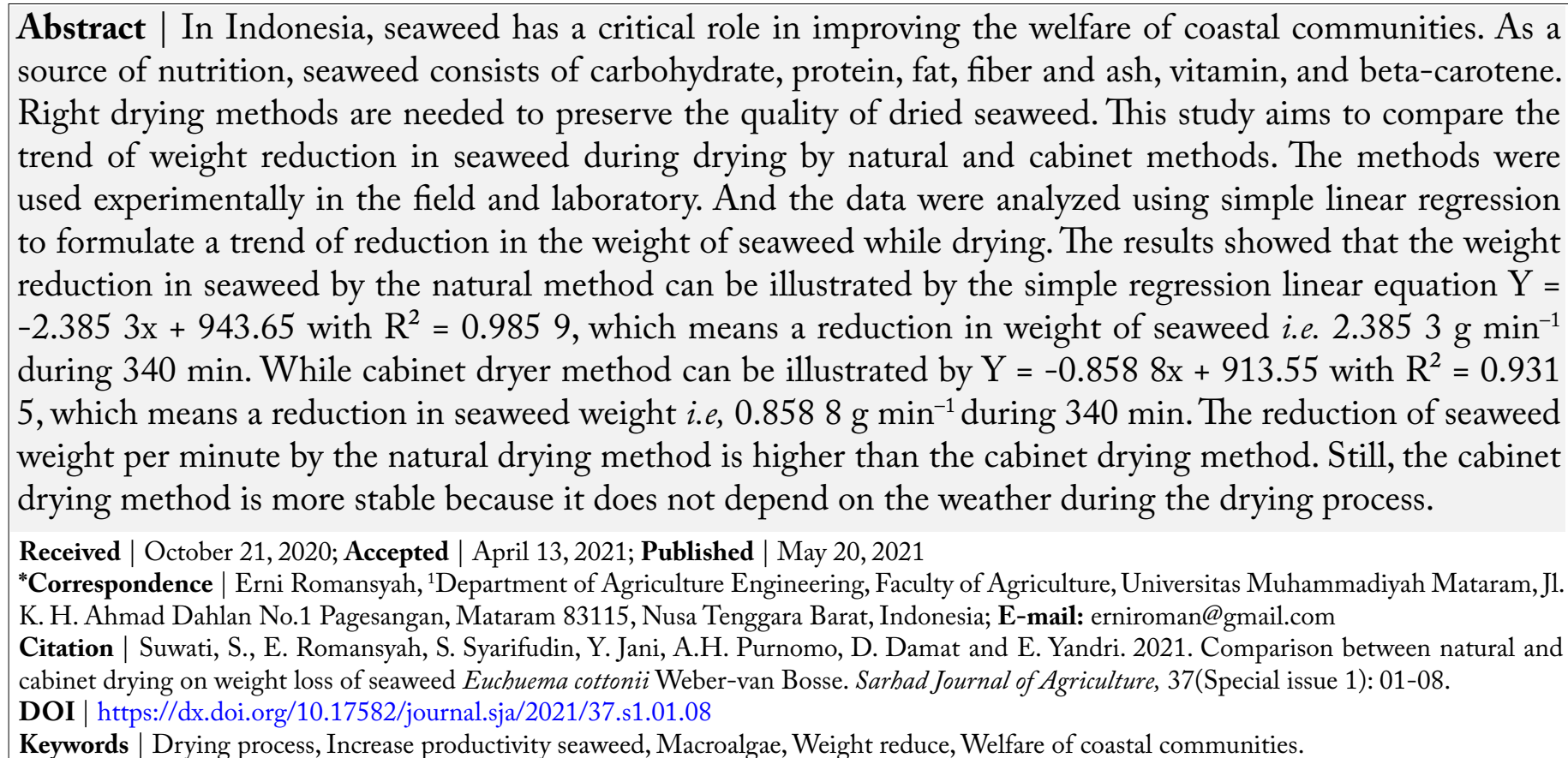

\section{Introduction}

Seaweeds are a group of photosynthetic nonflowering plant-like organisms (called macroalgae) that live in the sea (Sunarpi, 2017). Seaweed also is one of the versatile products used for food (McHugh, 2003). It has high water content when harvested.
However, for use sometime after harvesting, high water levels can trigger damage to seaweed. It is indicated that seaweed is easily damaged in fresh conditions (Pradana et al., 2013). This is caused by high water content, which makes physiological and enzymatic activity high, making it easy to cause mold growth or destruction. 
The drying method is an effort to decrease moisture content to prevent damage (Pradana et al., 2019) and so that seaweed products are safe to store for a long time. The decrease in seaweed water content is carried out by transferring water from the seaweed into the free air. Water vapor displacement occurs due to differences in vapor pressure in the material with the surrounding air.

A good drying method of seaweed will determine the length of time required without causes degrading quality. Generally, fishing communities dried the seaweed naturally by the sun by spread on bamboo woven media to receive sunshine (Kamaruddin et al., 2017, 2020).

The nutritional value of seaweed is high, being rich in carbohydrates, dietary fiber, fats and lipids, vitamins and minerals, especially iodine (Bouga et al.,2015).The nutritional composition of seaweeds varies depends on their species, maturity, environmental growth conditions such as seawater and sunlight (Xiren and Aminah, 2017). Seaweed inclusion in staple foods would serve as an alternative to the fortification of salt or other foods with KI (Combet et al., 2014). Seaweed nutrition content per $100 \mathrm{~g}$, i.e., the water content value of $13.90 \%$, ash content $3.40 \%$, protein $2.60 \%$, fat $0.40 \%$, carbohydrate $5.70 \%$, crude fiber $0.90 \%$, carrageenan $67.50 \%$, vitamin $\mathrm{C} 12.00 \%$, riboflavin 2.70 $\left(\mathrm{mg} 100 \mathrm{~g}^{-1}\right)$, mineral $22.39\left(\mathrm{mg}^{\left.100 \mathrm{~g}^{-1}\right), \mathrm{Ca} 2.30 \mathrm{mg}}\right.$ $\mathrm{kg}^{-1}$ and $\mathrm{Cu} 2.70 \mathrm{mg} \mathrm{kg}^{-1}$ (Anggadiredja et al., 2011).

So far, the quality produced by natural drying is quite good, but this method cannot be used at any time because it is constrained by the weather and the length of sun exposure. If the weather does not support, the drying seaweed time is $2 \mathrm{~d}$ to $4 \mathrm{~d}(\mathrm{~d}=$ day) until all is completely dry.

In West Nusa Tenggara (NTB) Indonesia, the type of seaweed Eucheuma cottonii Weber-van Bosseis widely developed and cultivated (Sahat, 2013). In 2016 recorded production of seaweed in NTB amounted to $11.68 \times 10^{6} \mathrm{t}$. While the total achievements of seaweed production in Lombok Island in 2016 amounted to $245.85 \mathrm{t}$ (DKP NTB, 2017). Besides, the current development of seaweed is one of the leading programs of the NTB provincial government, which is assembled in the PIJAR (Indonesian acronym: saPI, JAgung, Rumput laut) — cattle, corn, seaweedprogram.
The high level of production and the need for processed seaweed in NTB requires the handling of seaweed in a more appropriate way. Drying is a process to reduced water content from the substrate by thermal energy (Wilhelm et al., 2004). The benefit of drying is decreased water activity for inhibited growth of microbe and reduced storage volume (Shishir et al., 2017). Another drying method that can be a solution is to use a cabinet dryer who is a relatively simple artificial dryer, but its use is full enough for drying food (Siskawardani et al., 2021).

Cabinet dryer is a dryer food with a rack system (cabinet) multilevel uses sources heat from a supplemented LPG gas fire with blowers as heat spreaders as well-equipped temperature regulating valve with thermocouple to maintain no temperature change (Mardiah et al., 2012). According to Mardiah et al. (2012) and Siskawardani et al. (2021), drying cabinet (cabinet dryer) is a drying method by using a rack-shaped oven. Next, Suhardjo (2000) explained, the advantage of this drying is material becomes more durable and the volume of material becomes less so it makes transportation easier. In a tool that resembles this cabinet, the material is placed on a tray or pan and then arranged pad shelves are available.

The principle works are that dry air is blown through the heating media into the seaweed, accompanied by the process of moving water vapor out of the seaweed into the environment. The purpose of this research is to compare the trend of weight reduction in seaweed during drying by natural and cabinet.

\section{Materials and Methods}

Seaweed used is the Eucheuma cottonii variety because it is sought after and used for the food processing industry in NTB (Agus et al., 2021; Sunarpi, 2017). Also, of the 88 types of seaweed in NTB, E. cottonii is the most widely cultivated coastal community of NTB. Woven bamboo is used as a container for stretching seaweed to be dried (Kamarudin et al., 2020). An artificial dryer that looks like a closet arranged in the form of shelves, and the drying temperature can be controlled. Measuring instruments used to collect data are thermometers, hygrometers, lux meters, anemometers, and digital scales. Cabinet dryer that was used is an assembly made by a local factory with specifications type: DO-400-L; work area: $60 \mathrm{~cm}$ $\times 40 \mathrm{~cm} \times 165 \mathrm{~cm}$; stage: seven tray stainless steel; 
temperature range: ambient temperature - $\max 75^{\circ} \mathrm{C}$ $\pm 5{ }^{\circ} \mathrm{C}$; working time: $24 \mathrm{~h}$; temperature controller: automatic digital display; heater: lamp; air circulator: blower $25 \mathrm{~W}$; inside and outside material: stainless 201 ; and overall dimension is $80 \mathrm{~cm} \times 53 \mathrm{~cm} \times 190 \mathrm{~cm}$.

The research method used is experimental in the field and laboratory. The number of samples used was six samples consisting of two treatments each repeated three times. The variables observed in the area are sunshine intensity, ambient temperature, $\mathrm{RH}$, wind speed, and weight loss, while the settings found in the laboratory are weight loss. The data obtained were analyzed using simple regression analysis to determine the trend rate of weight loss of seaweed during drying using two methods, that is cabinet drying and sun drying like as shown in Figure 1. Figure 1A shows the cabinet dryer used, while Figure $1 \mathrm{~B}$ is the sun drying process in an open environment.
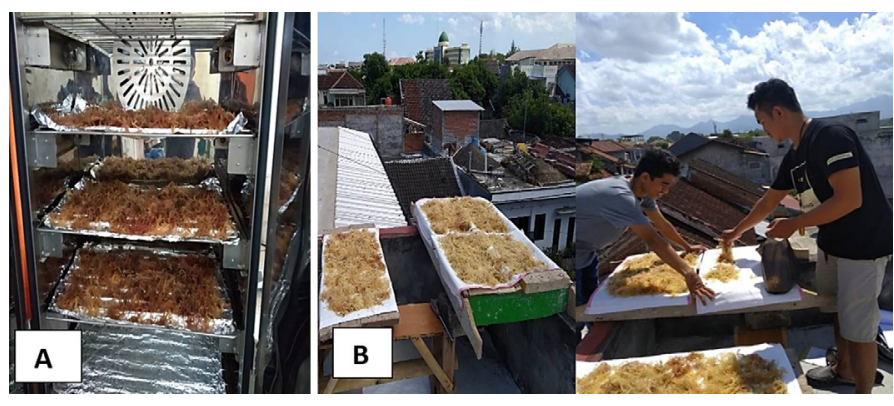

Figure 1: Cabinet dryer machine $(A)$ and tray manual sun drying (B).

\section{Results and Discussion}

Seaweed drying is a vital processing step because it is related to the high water content of the material as one of the main factors affecting the appearance, texture, taste, nutritional value of food. It's confirmed by a statement that fresh seaweed is easily damaged and rotted (Pradana et al., 2019). So, the drying method is an important step before seaweed is used in Industrial Processing (Gupta et al., 2011). Seaweed during drying will be loss on weight, and the color will change as shown in Figure 2.

Based on Figure 2, the color of fresh seaweed is bright green (Fig. 2A), while dry seaweed has a slightly yellowish brown color (Fig. 2B). The color change is influenced by the drying process and changes in moisture content.

In this study, the drying method used is direct drying with sunshine and using a cabinet dryer. The total drying time for both methods is the same, which is $340 \mathrm{~min}$. The results of this study compare the reduction in weight of the material using both ways.

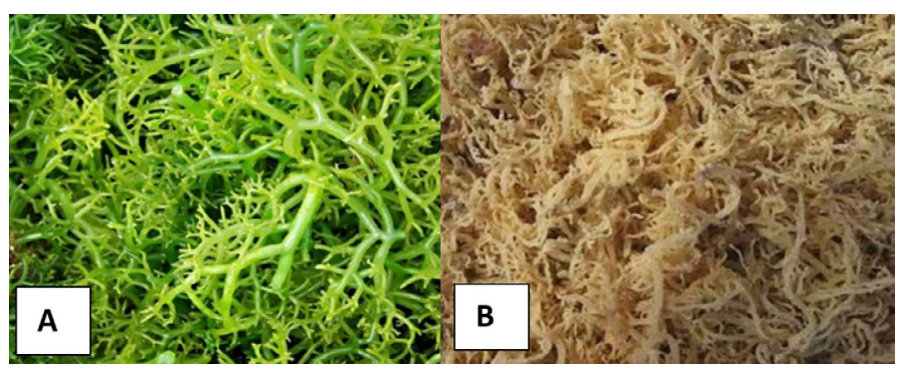

Figure 2: Fresh seaweed $(A)$ and dried seaweed (B) Eucheuma cottonii.

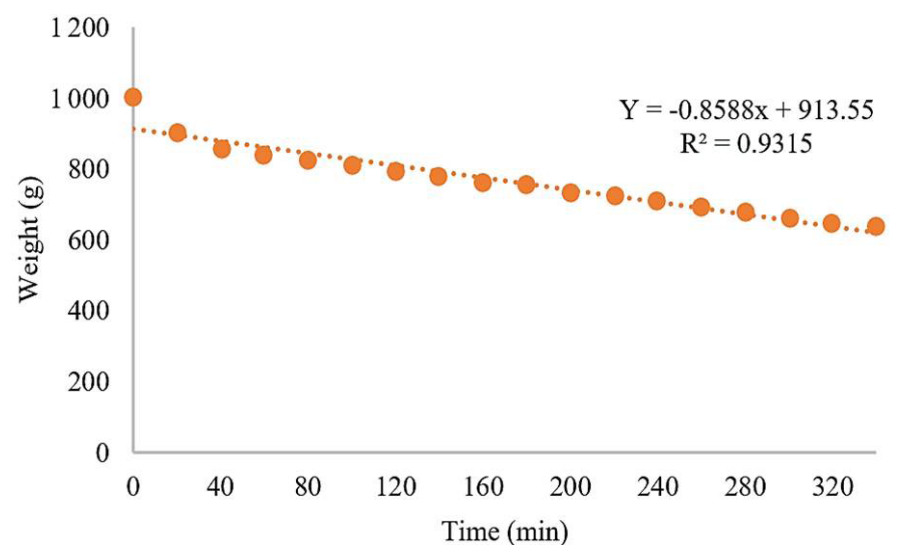

Figure 3: Reducing the weight of seaweed (g) at $40{ }^{\circ} \mathrm{C}$ used cabinet dryer.

\section{Seaweed drying with cabinet dryer}

Cabinet dryer uses depend on the drying temperature used and the time of drying, the longer the time of drying and the higher the temperature, which is then reduced levels of water will accelerate. The higher temperature increased moisture diffusivity as well as the constant drying rate (Mohamad and Sari, 2015). Drying seaweed using a cabinet dryer in this study was carried out at a temperature of $40{ }^{\circ} \mathrm{C}$, the results of drying are shown in Figure 3.

The use of drying temperature in the cabinet dryer can be more than $40{ }^{\circ} \mathrm{C}$, while the reason for using the $40{ }^{\circ} \mathrm{C}$ temperature is to approach the average temperature range for naturally drying using sunshine which when investigating ranges from $35{ }^{\circ} \mathrm{C}$ to 44 ${ }^{\circ} \mathrm{C}$ so that the drying conditions of the two are not much different. The higher the temperature used will undoubtedly speed up the drying process (Agarry et al.,2013). The average wind speed of the cabinet dryer that was used $0.53 \mathrm{~ms}^{-1}$. While the light intensity is average $2181 \mathrm{~lx}$. In this research, the wind speed data 
becomes the limitation of the formula in the dryer's implementation. Based on Figure 3, it can be seen that there is a decrease in seaweed weight during drying using a cabinet dryer with a temperature of $40{ }^{\circ} \mathrm{C}$. The declining trend of seaweed weight during drying is illustrated by the regression equation $Y=-0.8588 x$ +913.55 with a regression value of $\mathrm{R}^{2}=0.9315$. This means a decrease in seaweed weight by $0.8588 \mathrm{~g} \mathrm{~min}^{-}$ ${ }^{1}$ with a drying temperature of $40{ }^{\circ} \mathrm{C}$ using a cabinet dryer. The correlation value $\mathrm{R}^{2}=0.9315$, means that there is a close correlation or relationship between the drying time of the material weight reduction of $93 \%$ (Akpinar and Bicer, 2005). The equation of the rate of weight loss of seaweed obtained is then tested to simulate a prediction of seaweed weight reduction for $340 \mathrm{~min}$. The results of the prediction simulation can be seen in Figure 4.

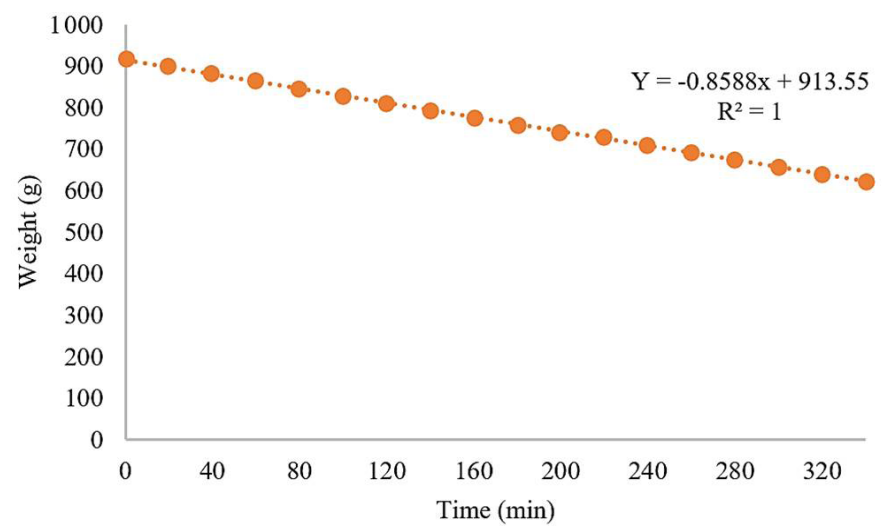

Figure 4: Prediction of the seaweed weight loss rate model.

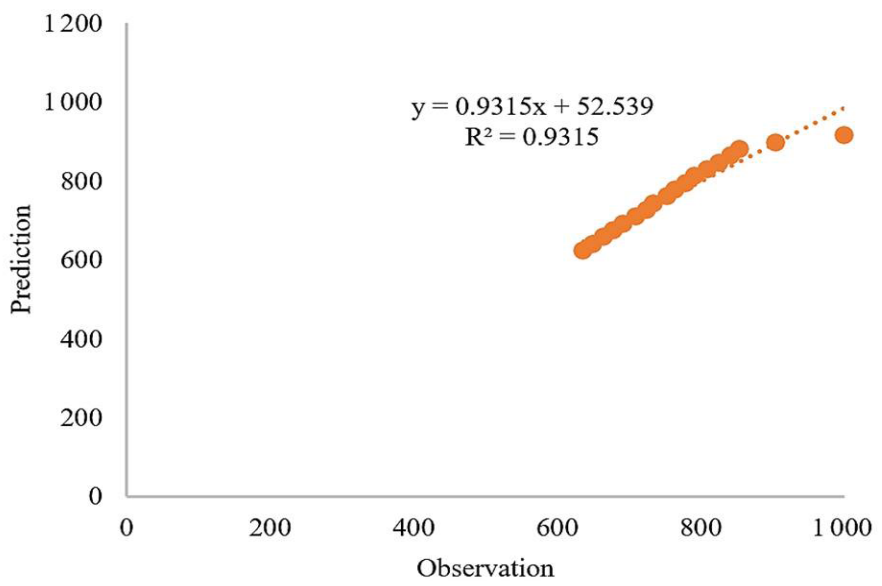

Figure 5: Validation of the seaweed weight reduction rate model.

Figure 4 shows the simulation trend of the prediction of the rate of decrease in seaweed weights. Seaweed weight decreases with increasing drying time (Waewsak et al., 2006) following the Regression equation $\mathrm{Y}=-0.8588 \mathrm{x}+913.55$ with $\mathrm{R}^{2}=1$.
Furthermore, the results of direct observations in the field are compared with the results of predictions made through the model (Gujral et al., 2006) validation process, and the results obtained are as shown in Figure 5.

In Figure 5, a high R-value on the graph shows the validity of the model (Jain and Pathare, 2007). This means that the model built is almost similar to real conditions on the ground.

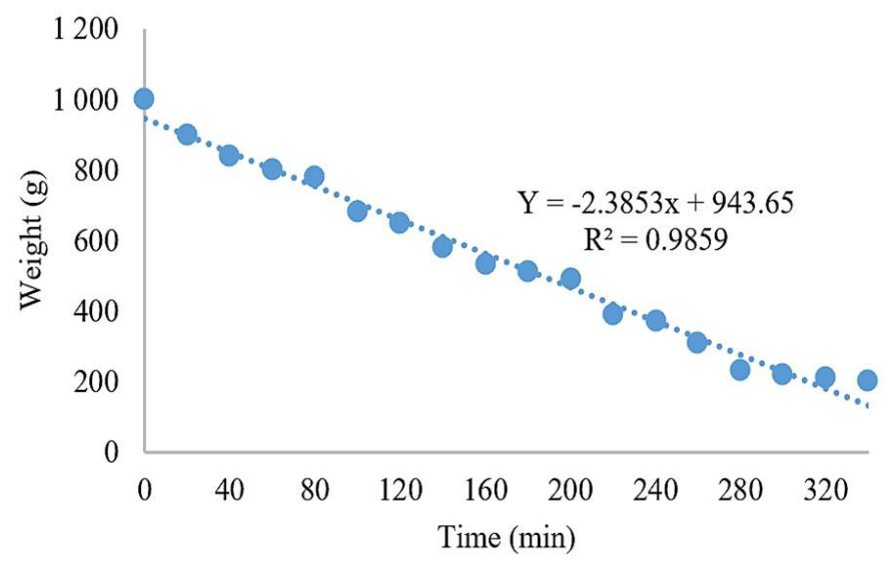

Figure 6: Decreased weight of seaweed with sunshine.

\section{Drying seaweed with sunshine}

Drying seaweed using a sun drying in this study was carried out at ambient temperature $\left({ }^{\circ} \mathrm{C}\right)$. During the observation there was a temperature fluctuation and could not be adjusted. The range temperature detected from $35{ }^{\circ} \mathrm{C}$ to $44{ }^{\circ} \mathrm{C}$, sunshine intensity up to 92000 lx, RH $40 \%$ to $51 \%$, wind speed average $1.28 \mathrm{~ms}^{-1}$. Full sun radiation occurs around 11.00 PM to 14.00 PM. So, the results of drying can be seen in Figure 6 .

Based on Figure 6, a decrease in weight seaweed occurred. Seaweed weight decrease over time (Agarry et al., 2013). The trend of decreasing seaweed weight during drying is illustrated by the simple regression equation $\mathrm{Y}=-2.3853 \mathrm{x}+943.65$ with a correlation value $R^{2}=0.9859$. This means a decrease in seaweed weight by $2.3853 \mathrm{~g} \mathrm{~min}^{-1}$ with a drying time of 340 min using sunshine. Correlation value $\mathrm{R}^{2}=0.985$ 9. This means there is a close correlation (Jain and Pathare, 2007) or human between drying time to decrease the weight of the material amounted to $98.59 \%$.

Based on the Indonesian National Standard (SNI) issued by the National Standard Agency (BSN), namely SNI 01-2690-1992 regarding the quality standards of dry seaweed that must be met, including 
moisture content, odor, foreign material, carrageenan content, and agar content as in Table 1.

Table 1: Quality standards of dry seaweed.

\begin{tabular}{lccccc} 
Test type & Unit & \multicolumn{5}{c}{ Requirements } \\
& & Eucheuma & Gelidium & Gracillaria & Hypnea \\
Moisture content & $\%$ & Max. 35 & Max. 15 & Max. 25 & Max. 20 \\
Odor & - & Unique & Unique & Unique & Unique \\
Foreign material & $\%$ & Max.5 & Max. 5 & Max.5 & Max. 5 \\
Carrageenan & $\%$ & Min. 25 & - & - & - \\
content & & & & & \\
Agar content & $\%$ & - & Min. 25 & Min.20 & - \\
\hline
\end{tabular}

Source: Dewan Standardisasi Nasional (1992).

The drying and storage of samples are likely to affect the moisture content of the samples examined, and seaweeds must meet the regulation of SNI 012690-1992 (Rasyid, 2017). According to research by Masduqi et al. (2014), there is a difference in the results of the proximate analysis of seaweed on oven drying and sun drying. Fiber content, crude protein, and an ash content of seaweed in oven drying were higher than sun drying. While the moisture content and fat content in oven drying are lower than in sun drying. This is because the drying process is not evenly distributed and temperature changes that fluctuate affect the moisture content. Chan (1997) was found that different drying methods have significant effects on the amount of nutritional composition extracted from seaweed $S$. hemiphyllum. But for economic reasons, sun-drying is widely used in both seaweed studies and the phycocolloid industry. Obstacle in sun-drying is strongly dependent on the weather and the length of the day (Kamaruddin et al., 2017).

Drying with a cabinet dryer applied to sliced bananas has better color, texture, and natural aroma when compared to drying in the open sun (Aruna et al., 2019). Badmus et al. (2019) also shown in their research that low-temperature drying, such as freezedrying and oven-drying at $40{ }^{\circ} \mathrm{C}$, produced products with higher concentrations of nutritionally important chemicals.

In the drying process, the heat transfer and mass transfer occurred. The heat from the drying medium will contact the product so that the water in the product will evaporate into the environment. For the clearly, the explanation on the mechanisms involved that cause the weight loss and changes observed have been shown in Figure 7.
Based on Figure 7, the drying process of seaweed occurs because of the transfer of heat from the heating medium (air) into the product accompanied by a process of transferring water vapor out of the product. The heating medium also functions to carry water vapor away from the product. The heat carrier medium is usually heated air.

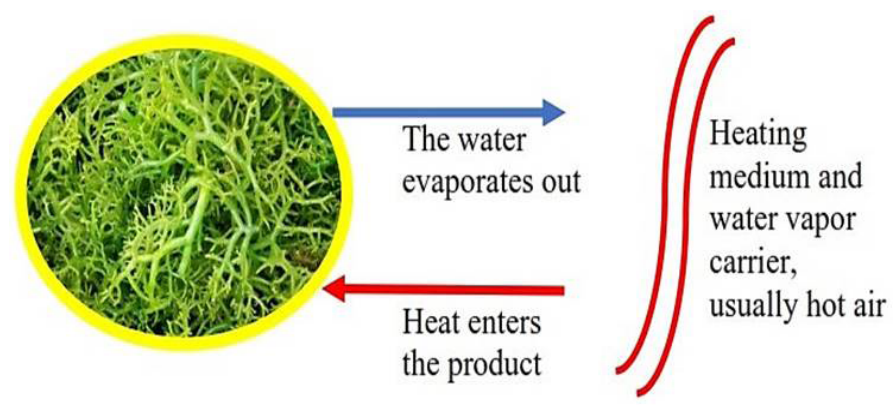

Figure 7: The drying process of seaweed.

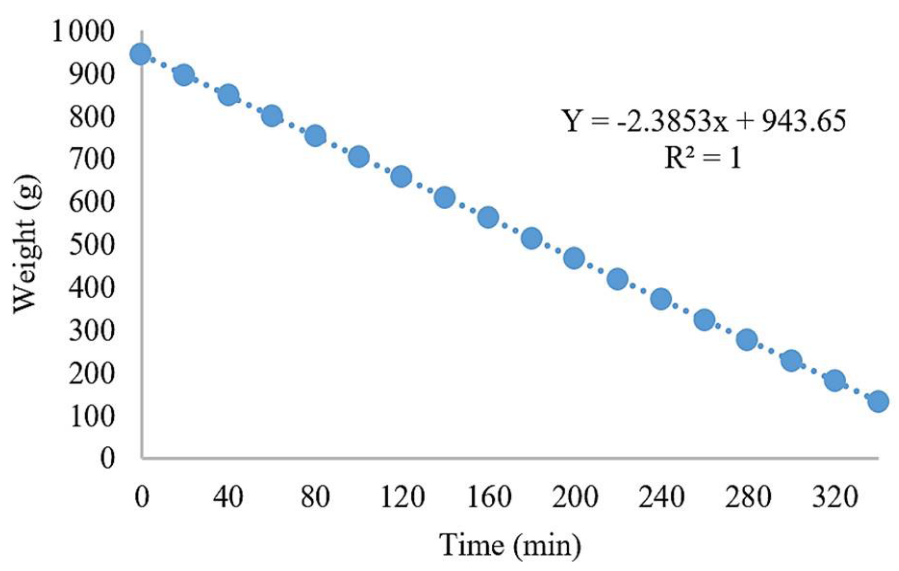

Figure 8: Prediction of the seaweed weight loss rate model.

The equation of the rate of weight loss of Seaweed obtained is then tested to simulate a prediction of seaweed weight reduction for $340 \mathrm{~min}$. The results of the prediction simulation can be seen in Figure 8.

Figure 8 shows the simulation trend of the prediction of the rate of decrease in seaweed weights. Seaweed weights decrease with increasing drying time following the Regression equation $Y=-2.3853 x+$ 943.65 with $\mathrm{R}^{2}=1$. Furthermore, the results of direct observations in the field are compared with the results of predictions made through the model validation process, and the results obtained are as shown in Figure 9. In Figure 9, a high R-value on the graph shows the validity of the model. This means that the model built is almost similar to real conditions on the ground (Waewsak et al., 2006). 


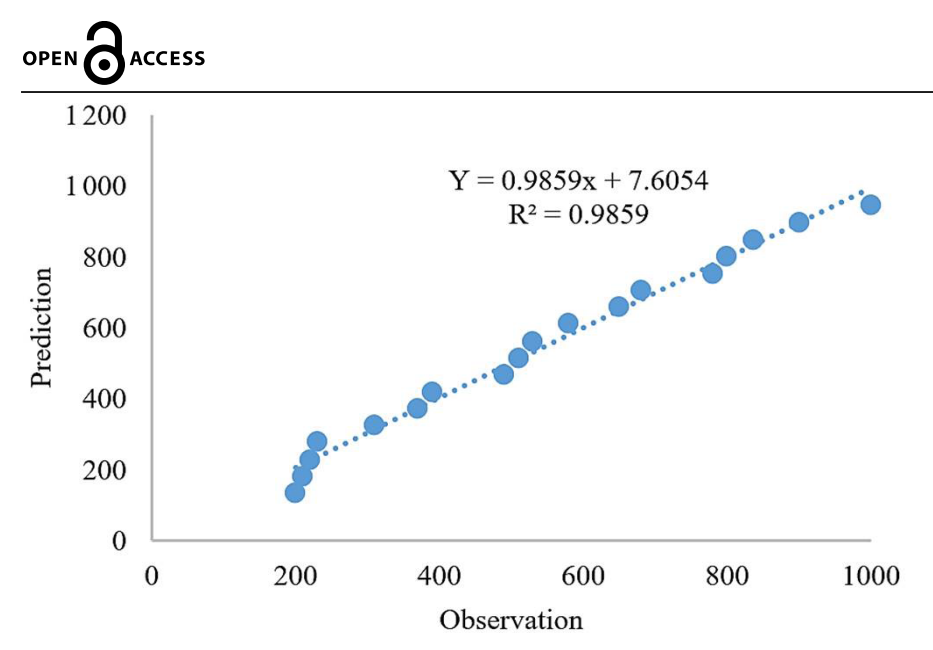

Figure 9: Validation of the seaweed weight reduction rate model.

The cabinet dryer method requires additional electric heating energy or LPG gas fire. That way, the future research direction is an economic study of this extra heating energy. The use of solar heating can be increased efficiency and effectiveness by applying a hybrid solar-wind dryer (Kamaruddin et al., 2017, 2020). The method of drying seaweeds with a hybrid renewable energy system should be studied and developed for the welfare of coastal communities.

In the research that has been carried out, in addition to weight reduction further testing has not been carried out on the chemical quality of dried seaweed. However, from the two methods, what meets the SNI standards is the result of drying with a cabinet dryer. Weight loss reaches $80 \%$. While the sun drying, the weight loss is $36.30 \%$. From the test, it can be seen that the drying time in the oven is shorter than the drying time in the sun because it does not depend on weather conditions. Cabinet drying can help overcome issues associated with prolonged duration of drying (Badmus et al., 2019).

But on the previous research which conducted by Masduqi et al. (2014), there is a difference in the results of the proximate analysis of seaweed on oven drying and sun drying. Fiber content, crude protein, and ash content of seaweed in oven drying were higher than sun drying. While the moisture content and fat content in oven drying are lower than in sun drying.

\section{Conclusions and Recommendations}

Based on the results of research and data analysis, it can be concluded that the weight reduction in the seaweed by the natural method is $2.3853 \mathrm{~g} \mathrm{~min}^{-1}$;

while by the cabinet dryer method it is $0.8588 \mathrm{~g}$ $\mathrm{min}^{-1}$. The reduction of seaweed weight per minute by the natural drying method is higher than the cabinet drying method. Still, the cabinet drying method is more stable because it does not depend on the weather during the drying process.

It is necessary to investigate further regarding the differences in the chemical quality of seaweed dried by the both methods, and next it is necessary to include all the variables which influence the mathematical formulation.

\section{Novelty Statement}

This research provides important information on prediction on the rate of weight reduction seaweed at a time with two different drying methods. This manuscript also shows that the weight-reduce seaweed by the natural method evidently can be illustrated by the simple regression linear equation. The natural method can be illustrated by $\mathrm{Y}=-2.385$ $3 \mathrm{x}+943.65$ with $\mathrm{R}^{2}=0.9859$. While by cabinet dryer method can be illustrated by $Y=-0.8588 x+913.55$ with $\mathrm{R}^{2}=0.9315$.

\section{Author's Contribution}

Suwati Suwati and Erni Romansyah conceive, design, the definition of intellectual content, literature search, data acquisition, data analysis, and statistical analysis, manuscript preparation, manuscript editing, and manuscript review. Syarifudin Syarifudin conducted Literature search, experimental studies, and manuscript review. Yahya Jani and Agus Heri Purnomo edited and review the manuscript, and guarantor. Damat Damat and Erkata Yandri done literature search, data analysis, and manuscript review. All authors read and approved the final manuscript.

\section{Conflict of interest}

The authors declare that there is no conflict of interests regarding the publication of this article.

\section{References}

Agarry, S.E., A.O. Ajani and M.O. Aremu. 2013. Thin layer drying kinetics of pineapple: Effect of blanching temperature-time combination. Nig. J. Basic Appl. Sci., 21: 1-10. https://doi. org/10.4314/njbas.v21i1.1 
Agus, H.P., R. Kusumawati, A. Pratitis, I. Alimin, S. Wibowo, M. Rimmer and N. Paul. 2021. Improving margins of the Indonesian seaweed supply chain upstream players: The application of the Kaizen approach. E3S Web Conf., 226: 1-11. https://doi.org/10.1051/ e3sconf/202122600004

Akpinar, E.K. and Y. Bicer. 2005. Modelling of the drying of eggplants in thin layers. Int. J. Food Sci. Technol., 40: 273-281. https://doi. org/10.1111/j.1365-2621.2004.00886.x

Anggadiredja, J.T., M.A. Widodo and A. Djatnik. 2011. Kajian strategi pengembangan industry rumput laut dan pemanfaatannya secara berkelanjutan [Study on seaweed industry development strategy and its sustainability]. Sumberdaya Alam Deputi Bidang TPSA BPPT, Jakarta.

Aruna, K.R., M. Srinivasa, C.A. Saleelb and S. Jayaraja. 2019. Active drying of unripened bananas (Musa Nendra) in a multi-tray mixedmode solar cabinet dryer with backup energy storage. Sol. Energy, 188: 1002-1012. https:// doi.org/10.1016/j.solener.2019.07.001

Badmus, U.O., M.A. Taggart and K.G. Boyd, 2019. The effect of different drying methods on certain nutritionally important chemical constituents in edible brown seaweeds. J. Appl. Phycol., 31: 3883-3897. https://doi.org/10.1007/s10811019-01846-1

Bouga, M. and E. Combet. 2015. Emergence of seaweed and seaweed-containing foods in the UK: Focus on labeling, iodine content, toxicity and nutrition. Foods, 4: 240-253. https://doi. org/10.3390/foods4020240

Chan, J.C.C., P.C.K. Cheung and P.O. Ang, Jr. 1997. Comparative studies on the effect of three drying methods on the nutritional composition of seaweed Sargassum bemiphyllum (Turn.) C. Ag. J. Agric. Food Chem., 45: 3056-3059. https://doi.org/10.1021/jf9701749

Combet, E., Z.F. Ma, F. Cousins, B. Thompson and M.E. Lean. 2014. Low-level seaweed supplementation improves iodine status in iodine-insufficient women. Br. J. Nutr., 112: 753-761. https://doi.org/10.1017/ S0007114514001573

Dewan Standardisasi Nasional, 1992. SNI 012690. Rumput Laut Kering (Dried Seaweed). Dewan Standardisasi Nasional (National Standardization Council), Jakarta.
DKP NTB, 2017. Statistics of aquaculture NTB province maritime and fisheries. Dinas Kelautan dan Perikanan Provinsi NTB, Mataram, Lombok., West Nusa Tenggara.

Gujral, H.S., D.P.S. Oberoi, R. Singh and M. Gera. 2013. Moisture diffusivity during drying of pineapple and mango leather as affected by sucrose, pectin and maltodextrin. Int. J. Food Prop., 16: 359-368. https://doi.org/10.1080/10 942912.2011.552016

Gupta, S. and N. Abu-Ghannam. 2011. Recent developments in the application of seaweeds or seaweed extracts as a means for enhancing the safety and quality attributes of foods. Innov. Food Sci. Emerg. Technol., 12: 600-609. https://doi.org/10.1016/j.ifset.2011.07.004

Jain, D. and P.B. Pathare. 2007. Study the drying kinetics of open sun drying of fish. J. Food Eng., 78: 1315-1319. https://doi.org/10.1016/j. jfoodeng.2005.12.044

Kamaruddin, A., A.S. Uyun, H.N. Rahman, E. Suherman and S.Y. Lumbessi. 2017. Using renewable energy to process Seaweed. In: Mediterranean green buildings and renewable energy (ed. A. Sayigh). Springer, pp. 835-843. https://doi.org/10.1007/978-3-319-307466_65

Kamaruddin, A., A.S. Uyun, R. Soegeng, E. Suherman, H. Susanto, R.H. Setyobudi, J. Burlakovs and Z. Vincēviča-Gaile. 2020. Renewable energy technologies for economic development.E3S Web Conf., 188:1-8. https:// doi.org/10.1051/e3sconf/202018800016

Mardiah, N. and N. Mashudi. 2012. Determination of dryingmethod (cabinet dryer and fluidizedbed dryer) on compound and capasity antioxidant in dried rosela. J. Pertanian, 3: 104-110.

Masduqi, A.F., M. Izzati and E. Prihastanti. 2014. Effects of drying methods on chemical content in seaweed Sargassum polycystum. Bull. Anat. Fisiol., 22: 1-9.

McHugh, D.J. 2003. A guide to the seaweed industry. FAO Fisheries Technical Paper No. 441.

Mohamad, D. and D.A. Sari. 2015. Low temperature seaweed drying using dehumidified air. International Conference on Tropical and Coastal Region Eco-Development (ICTCRED 2014). https://doi.org/10.1016/j.proenv.2015.01.002

Pradana, G.B., K.B. Prabowo, R.P. Hastuti, M. Djaeni and A. Prasetyaningrum. 2019. Seaweed drying process using tray dryer with de- 
humidified air system to increase efficiency of energy and quality product. IOP Conf. Ser.: Earth Environ. Sci., 292: 1-7. https://doi. org/10.1088/1755-1315/292/1/012070

Pradana, O.Y., N. Soenardjo and S. Sunaryo. 2013. Bioecology study and mangrove ecosystem management strategy: Case study in Awur Bay, Jepara. J. Mar. Res., 2: 54-61.

Rasyid, A. 2017. Evaluation of nutritional composition of the dried seaweed Ulva lactuca from Pameungpeuk Waters, Indonesia. Trop. Life Sci. Res., 28: 119-125. https://doi.org/10.21315/ tlsr2017.28.2.9

Sahat, H.J. 2013. Indonesian sea weed. Warta ekspor Ditjen PEN, Kementerian Perdagangan, 70: 8-11.

Shishir, M.R.I. and W. Chen. 2017. Trends of spray drying: A critical review on drying of fruit and vegetable juices. Trends Food Sci. Technol., 65: 49-67. https://doi.org/10.1016/j. tifs.2017.05.006

Siskawardani, D.D., W. Sri and K. Khawwee. 2021. The antioxidant activity of Kelor (Moringa oleifera Lam.) leaves based on drying method. Jor- dan J. Biol. Sci., In Press.

Suhardjo, Y. and P. Santoso. 2000. Determination of drying method and fruit maturity in preparing chips of mango CV. Arumanis. Proc. Sixth Int'1 Mango Symp. Acta Hort, ISHS. https:// doi.org/10.17660/ActaHortic.2000.509.59

Sunarpi. 2017. Promotion of NTB seaweed at the Asia Pacific Phycology Forum. Radar Lombok. Available at: http://radarlombok.co.id/sunarpi-promosi-rumput-laut-ntb-di-forum-ilmuan-asia-pasific.html

Waewsak, J., S. Chindaruksa and C. Punlek. 2006. A mathematical modeling study of hot air drying for some agricultural products. Thammasat Int. J. Sci. Tech., 11: 14-20.

Wilhelm, R.L., D.A. Suter and G.H. Brusewitz. 2004. Food and process engineering technology. ASAE, St. Joseph, MI, pp. 259-284. https:// doi.org/10.13031/2013.17918

Xiren, G.K. and A. Aminah. 2017. Proximate composition and total amino acid composition of Kappaphycus alvarezii found in the waters of Langkawi and Sabah, Malaysia. Int. Food Res. J., 24: 1255-1260. 